\title{
AN ANALYSIS OF DEIXIS AND ITS REFERENCE USED BY MAIN CHARACTER IN “A THOUSAND WORDS” MOVIE SCRIPTBY STEVE KOREN
}

\author{
Raty Sasmita \\ University of Bengkulu, \\ ratysasmita@gmail.com \\ Mei Hardiah \\ University of Bengkulu, \\ mei_bungsu@gmail.com \\ Elfrida \\ University of Bengkulu, \\ miss.elfrida@gmail.com
}

\begin{abstract}
The type of this research is Descriptive Qualitative research. It is aimed to find out the types of Personal, Time, Place, Discourse and Social Deixis and its reference by main character in "A Thousand Words" movie script based on the theory that proposed by Levinson. The object of this study is "A Thousand Words" movie script by Steve Koren. This research found the five types of deixis in movie script, they are person deixis (515 occurences), time deixis (20 occurences), place deixis (34 occurences), discourse deixis (104 occurences) and social deixis ( 1 occurence). Beside that, the references found in this research were in person deixis were I, Me, We, Us, My as first person deixis; You, Your as second person deixis; He, She, It, They, Them, Him, Her as third person deixis which belong to personal deixis (149 utterances); time deixis found were Now, Today, On a Tuesday, Three days, Two days, Then (19 utterances); place deixis found were Here, There, In (22 utterances); discourse deixis found were This, That, Those, These (60 utterances); ands the last, social deixis found were Mr (1 utterance).
\end{abstract}

Keywords: Pragmatics, Deixis, Reference, A Thousand Words.

\begin{abstract}
Abstrak
Penelitian ini adalah Penelitian Deskriptif Kualitatif. Penelitian ini bertujuan untuk menemukan tipe-tipe Deiksis dan rujukannyanya oleh pemeran utama dalam Film "A Thousand Words" berdasarkan teori yang dikemukakan oleh Levinson. Objek dari penelitian ini adalah naskah film "A Thousand Words" yang ditulis oleh Steve Koren. Penelitian ini menemukan lima tipe deixis di naskah film, kelima tipe itu adalah deiksis personal (515 kejadian), deiksis waktu (20 kejadian), deiksis tempat (34 kejadian), deiksis wacana (104 kejadian) dan deiksis sosial (1 kejadian). Disamping itu, rujukan ditemukan di penelitian ini adalah I, Me, We, Us, My sebagai deiksis orang pertama; You, Your sebagai deiksis orang kedua; He, She, It, They, Them, Him, Her sebagai deiksis orang ketiga yang termasuk kedalam deiksis personal (149 ucapan); deiksis waktu ditemukan adalah Now, Today, On a Tuesday, Three days, Two days, Then (19 ucapan); deiksis tempat ditemukan adalah Here, There, In (22 ucapan); deiksis wacana ditemukan adalah This, That, Those, These sebagai deiksis wacana (60 ucapan); deiksis sosial ditemukan adalah Mr (1 ucapan).

Kata Kunci: Pragmatik, Deiksis, Rujukan, A Thousand Words.
\end{abstract}




\section{INTRODUCTION}

Language is used for communcation, sometime the utterances delivered by the speaker to the listener or address are ambiguous. In English actually, sometimes the hearer or address feels difficult to understand about what the speaker says about whom, when, and where. This situation can make the problem of communication. According to Levinson (1983:21) states that pragmatics is the study of relations between language and context that are basic to an account of language understanding.

Deixis is the study of deictic or indexical expressions in language dialogues, prologues, and monologue like you, now, today. Deixis can be classified as a special kind of grammatical property, dealing with more familiar grammatical categories of personal, place, time. Usually it has relationship with context of the utterance, such as who is speaking, the time or place of speaking, the gestures of the speaker, or the current location in the discourse. Deixis is always found in our daily communication or in text. As Yule (1996:9) states that deixis is pointing via language.

As stated by Levinson $(1983 ; 2004)$ theory, there are five types of deixis, there are person deixis, time deixis, place deixis, social deixis, and discourse deixis. The categories can be used to analyse the language that sometimes the listener does not understand about what the speaker means. So, deixis can make the language easier to understand.

This topic is important to be analyzed because we have learned about deixis in pragmatics subject. When the speakers and listeners get miscommunication about meaning of word that is related to the context of situation and if the listeners know the context, the language can be understood clearly about meaning. Deixis is very important to study as one of the teaching materials or instructional media in order to facilitate the students to understand and how to analyze the movie. Furthermore, it chooses movie and made the students use it as a media to learn deixis.

Based on the explanation on the background above, the researcher found out :

1. What are the types of deixis used by main character in "A Thousand Words" movie script by Steve Koren?

2. What are the references of the deixis used by main character in "A Thousand Words" movie script by Steve Koren?

\section{METHOD}

The researcher used a descriptive qualitative research method. It means that the data which are analyzed have the form of descriptive, not nominal form. According to Gay (1991), descriptive method is considered appropriate to describe the present condition of research subject. Arikunto (2002) also states that the descriptive research as a research that explains or describe the present condition. Based on the opinions, the researcher designed this research as descriptive qualitative research. The instrument of this research was the researcher herself (human instrument). It means the researcher as the instrument that is involved in this research to conduct the research and find the data. Mukhtar (2013) states that we are a instrument or tool of direct observation, because all sense of researcher is essentially a tool of observation. the researcher focused on deixis and its reference used by main character in the movie script "A Thousand 
Words" by Steve Koren. In data collection, the researcher did some step. Firstly, the researcher watch A Thousand Words movie and then downloaded the script from

http://www.springfieldspringfield.co.uk after that, observed the utterances in the movie`s dialogue, and then compared the dialogue in the film to the script and then the researcher identified the utterance in the whole of film is dialogue that contain deixis, then, separated some dialogue that contains the main character of film, after that classified the utterance by main character on A Thousand Words movie based on the type, the last step is described the context by main character on A Thousand Words movie based on the type.

\section{RESULT AND DISCUSSION Result}

The researcher found out the deixis of main character used in this movie used Levinson theory. There were many deixis found in A Thousand Words movie dialogue. The researcher shows the table that present the first result of types of deixis.

\begin{tabular}{|c|c|c|c|}
\hline \multirow{2}{*}{ No } & \multicolumn{2}{|c|}{ Personal Deixis } & Frequency \\
& \multicolumn{2}{|c|}{ Types / Category } & of Types \\
\hline \multirow{4}{*}{1} & \multirow{3}{*}{ 1st } & Me & 168 \\
& person & We & 43 \\
& & Us & 3 \\
& & My & 34 \\
\hline \multirow{2}{*}{2} & 2nd & You & 140 \\
& person & Your & 25 \\
\hline \multirow{4}{*}{3} & & He & 14 \\
& & She & 2 \\
& & It & 61 \\
& prd & They & 5 \\
& & Them & 3 \\
& & Him & 2 \\
& & Her & 3 \\
\hline
\end{tabular}

\section{Total}

515

Based on the findings above, the researcher found that first person deixis was as a dominant in personal deixis, because the word "I, Me, My, We and Us" refer to main character, Jack in "A Thousand Words" movie script, which consisted of first person used 260 times. The second dominant was second person deixis. The word "You and Your" refered to the listener or addressee in conversation movie script, which consisted of second person used 165 times. The next was third person deixis which consist used 90 times. The word "He, She, It, Him and Her" They and Them" refered to the listener or addressee in conversation movie script.

\begin{tabular}{|c|c|c|c|}
\hline \multirow{2}{*}{ No } & \multicolumn{2}{|c|}{ Time Deixis } & \multirow{2}{*}{$\begin{array}{c}\text { Frequency } \\
\text { of Types }\end{array}$} \\
\hline & \multicolumn{2}{|c|}{ Types / Category } & \\
\hline \multirow{2}{*}{1} & Adverb & Now & 14 \\
\hline & of Time & Today & 2 \\
\hline \multirow{4}{*}{2} & & On a Tuesday & 1 \\
\hline & The & Three days & 1 \\
\hline & Phrases & Two days & 1 \\
\hline & & Then & 1 \\
\hline \multicolumn{3}{|c|}{ Total } & 20 \\
\hline
\end{tabular}

Based on the findings above, the researcher found the word "now" as a dominant in time deixis was consist used 14 times. It was spoken by Jack. The word "now" was deixis expression because it refers to duration of specch event. The second dominant was the word "today" which consist used 2 times, "on a Tuesday" used 1 time, "three days" used 1 time, "two days" used 1 time and "then" used 1 time. It was also spoken by main character. The phrase "today, on a Tuesday, three days, two days and then" was deixis expression because it points, duration when speech events happen. 


\begin{tabular}{|c|c|c|c|}
\hline \multirow{2}{*}{ No } & \multicolumn{2}{|c|}{ Place Deixis } & Frequenc \\
\cline { 2 - 3 } & \multicolumn{2}{|c|}{ Types / Category } & of \\
\hline \multirow{2}{*}{1} & Proximal & $\begin{array}{c}\text { Here } \\
\text { In }\end{array}$ & $\begin{array}{c}14 \\
\end{array}$ \\
\hline 2 & Distal & There & 12 \\
\hline \multicolumn{3}{|c|}{ Total } & $\mathbf{3 4}$ \\
\hline
\end{tabular}

Based on the findings above, the researcher found the word "Here" as the most dominant word in place deixis which was used 14 times. It was spoken by main character in "A Thousand Words" movie script. The word "here" was included into place deixis because it points the place near the speaker in the speech event. The second dominant was the word "There" which was used 12 times. The word "there" was deixis expression because the distance of the speaker away from addressee. The last was the word "in" which was used 8 times. It points the place that speech event occurs. Place deixis focus on the place where the speech event occurs and deal with the distance.

\begin{tabular}{|c|c|c|c|}
\hline \multirow{2}{*}{ No } & \multicolumn{2}{|c|}{ Discourse Deixis } & \multirow{2}{*}{$\begin{array}{c}\text { Frequency } \\
\text { of Types }\end{array}$} \\
\hline & \multicolumn{2}{|c|}{ Types / Category } & \\
\hline \multirow{2}{*}{1} & Provimal & This & 42 \\
\hline & rioximadi & These & 2 \\
\hline \multirow{2}{*}{2} & \multirow{2}{*}{ Distal } & That & 59 \\
\hline & & Those & 1 \\
\hline \multicolumn{3}{|c|}{ Total } & 104 \\
\hline
\end{tabular}

Based on the findings above, the researcher found that the word "That" was a dominant word in discourse deixis which was used 59 times. It was spoken by main character in "A Thousand Words" movie script. The word "that" was deixis expression because the distance of the speaker was away from addressee. The second dominant was the word "this" which was used 42 times. The word "this" was included into discourse deixis because it points the discourse near the speaker in the speech event. The word "that and this" denotes a deixis expression because they refer to Jack's utterance. By this consideration, words (this and that) has deep meaning. The last is the word "these" plural from "this" which was used 2 times and the word "those" prural from "that" which was used 1 time.

\begin{tabular}{|c|c|c|c|}
\hline \multirow{2}{*}{ No } & \multicolumn{2}{|c|}{ Social Deixis } & Frequency \\
\cline { 2 - 3 } & \multicolumn{2}{|c|}{ Types / Category } & of Types \\
\hline 1 & Social Deixis & $\mathrm{Mr}$ & 1 \\
\hline \multicolumn{2}{|c|}{ Total } & $\mathbf{1}$ \\
\hline
\end{tabular}

Based on the findings above, the researcher found the word "Mr" in social deixis which consist used 1 time. It was spoken by main character in "A Thousand Words" movie script. The word "Mr" is proper name. It can be included into social deixis because it was indicated relation that occurs in social situation between Dr. Sinja and the tree. According to this movie the word "Mr" is polite and it gives social distance between speaker and addressee.

The second result about reference meaning by main character in A Thousand Words movie script by Steve Koren. The references found in this research were in person deixis were I, Me, We, Us, My as first person deixis; You, Your as second person deixis; He, She, It, They, Them, Him, Her as third person deixis which belong to person deixis; time deixis found were Now, Today, On a Tuesday, Three days, Two days, Then; place deixis found were Here, There, In; discourse deixis found were This, That, Those, These; and the last, social deixis found were Mr.

\section{Discussion}

In discussion, the researcher describes the finding of the results. The first problem in this research is "What were the types of deixis used by main character in "A Thousand Words" movie 
script by Steve Koren". To answer this question, the researcher selected the theory of Levinson (1983). Levinson states that there are five kinds of deixis, they are: person deixis, place deixis, time deixis, discourse deixis, and social deixis. The researcher also found five kinds of deixis used by main character in " $A$ Thousand Words" movie script.

This research found the five types of deixis in movie script, they are person deixis (515 occurences), time deixis (20 occurences), place deixis (34 occurences), discourse deixis (104 occurences) and social deixis (1 occurence). Beside that, the references found in this research were in person deixis were $\mathrm{I}, \mathrm{Me}, \mathrm{We}, \mathrm{Us}, \mathrm{My}$ as first person deixis; You, Your as second person deixis; He, She, It, They, Them, Him, Her as third person deixis which belong to person deixis (149 utterances); time deixis found were Now, Today, On a Tuesday, Three days, Two days, Then (19 utterances); place deixis found were Here, There, In (22 utterances); discourse deixis found were This, That, Those, These $(60$ utterances); and the last, social deixis found were $\mathrm{Mr}$ (1 utterance).

In this discussion, the researcher discussed about person deixis firstly. The researcher found some utterances, like " $I$ ' $m$ not. You sure she should be drinking these margaritas?" This utterance was said by main character, Jack. The word "I" is categorized into person deixis because singular pronoun " 1 " refers to speaker himself as first person. The following, the word "you" is included into person deixis because pronoun "you" refers to second person or addressee. The last, the word "she" is person deixis because singular pronoun "she" refers to third person who does not correspond to any specific participant-role in the speech event. Based on Levinson theory (1983), the person deixis identified the words of first person deixis, in singular pronouns ( $I, m e$, myself, my, mine), and plural pronouns (we, us, ourselves, our, ours), second person deixis in singular pronouns (you, yourself, your, yours) and plural pronouns (you, yourselves, your, yours) and third person deixis in singular pronouns (he, him, his, she, her, it) and plural pronouns (they, them, their).

The second was time deixis. The researcher found the utterance "No, I gotta make nice. I'll keep it. This is my tree now." the word "now" is categorized into time deixis because it refers to duration of speech event. It is also used in Levinson theory (1983) that time deixis is identified by adverbial of time. The researcher also found the words "today" in the conversation by main character as adverb of time. The researcher also found the phrases "three days, then, on a Tuesday and two days" are deitic expression because they refer to duration when speech events happen. So, they can be categorized into time deixis. So, it can be categorized into time deixis.

The third was place deixis. The researcher found the utterance "Hola, Gaudencio. "You're here late, huh?" in the conversation by main character. The deixis occur in this utterance is place deixis it particularly obvious in terms of deitic expression. Based on Levinson Theory (1983), the word "here" was categorized into place deixis. It refers to place or situation near speaker. The word "here" in that sentence pointed to current place namely Jack's house. The researcher also found the utterance "I wish there was a way I could make it up to you". The word "there" is deitic expression because the distance of the speaker away from addressee, it can be categorized into place deixis.The researcher also found the word 
"in a world, in the room, in a elevator, in a restaurant, in the ass and in this room" that was found in conversation was spoken by main character. Based on the context of conversation, it points the place where speech even occurs. Place deixis focus on the place where the speech event occurs and deal with the distance. So, the words "in a world, in the room, in a elevator, in a restaurant, in the ass and in this room" can be included into place deixis.

The fourth was discourse deixis. In the A Thousand Words movie script, the researcher found the utterance "Okay, Aaron, come on. Tell me that you're pulling my pecker on this one, right?" based on Levinson theory (1983), in the discourse deixis, the referent of speaker may point in the previous, at the point, and the next. The researcher found the words "this" and "that" as deitic expression that were said by main character, They refers to situation near speaker and distance of the speaker away from addressee. Based on the context of conversation, the word "this" and "that' were categorized into discourse deixis because they refer to previous text of Aaron' utterance.

The last is social deixis. In this movie script, the researcher found an utterance "You know what, Sinja? You worry about pages six through 200 and you let me worry about Mr. Tricky Tree over here! And on that note, one last final word! Timber!". It was spoken by main character. The word "Mr" is proper name and it refers to Tricky Tree. The word "Mr" is included into social deixis because based on the context, it occured the relation in social situations between Dr. Sinja and the tree. Levinson (1983) states that social deixis concerns the encoding of social distinctions that are relative to participant-roles, particularly aspects of the social relationship holding between speaker and addressee or speaker and some referent. In this way, we can know social deixis can be identified clearly using context of utterance because not all pronoun is deixis. Deixis can be categorized into its part if the reverent has the clear purpose of utterance.

The second problem in this research was "What was the reference of the deixis used by main character in "A Thousand Words" movie Script by Steve Koren?" To answer this question, the researcher classified each utterances belongs to each deixis by main character. There are 160 utterances of the reference meaning of deixis used by main character in "A Thousand Word" movie script.

In this research, the most dominant reference of the deixis found in this movie script was personal deixis which consist of 149 utterances and 515 times, there were first person deixis, in singular pronouns "I, me, myself, my, mine", and plural pronouns "we, us, ourselves, our, ours", second person deixis in singular pronouns "you, yourself, your, yours" and plural pronouns "you, yourselves, your, yours" and third person deixis in singular pronouns "he, him, his, she, her, it" and plural pronouns "they, them, their", because main character in this movie script always used personal deixis to refer the addressee.

The second dominant deixis was discourse deixis, which was 104 times and 60 utterances. The words "this" and "that" as deitic expression that were said by main character, because the main character used "this" and "that" to refers the situation near speaker and distance of the speaker away from addressee. 
The third dominant deixis was place deixis, which was 22 utterances and 34 times. The words "there, here, in a world, in the room, in a elevator, in a restaurant, in the ass and in this room" that was found in conversation was spoken by main character, because the speaker focus on the place where the speech event occurs and deal with the distance.

The fourth dominant deixis was time deixis, which consist of 19 utterances and 20 times. There were adverb of time "“now and today", the phrases "three days, then, on a Tuesday and two days" in the conversation by main character, because they were deitic expression and they refered to duration when speech events happen.

The least dominant deixis in "A Thousand Words" was social deixis, which was 1 utterance and 1 time. Because the main character (Jack) is someone with a high ambition, whatever he wants he should get. It makes the main character become a selfish person and did not care about the people around him and makes him impolite with other people and does not care about who and what the person's have or their position. That's why social deixis became the least dominant found in this research. The main character only used " $M r$ " for social distinctions between speaker and addressee.

The finding of this research is similar with Tulah (2015) and Setyawati (2013) who found person deixis as the most dominant. However, there is a difference with Setyawati's research. Her research analyzed novel as a object but this research analyze movie script. The difference in the order of dominant deixis, this research the most dominant deixis found was person deixis, discourse deixis, time deixis and the last social deixis as less dominant deixis found "A Thousand Words" movie script. While Setyawati's research the most dominant deixis found was personal deixis, temporal deixis (time), discourse deixis and the last spatial deixis (place) as least dominant deixis found. There is no social deixis found in her research and she use Yule theory but my research use Levinson theory.

The person deixis become the most dominant deixis found in this movie because the main character (Jack) is someone with a high ambition, whatever he wants he should get it. He likes to talk and promote himself to get attention. He loves talking and introduces himself. The main character many used person deixis to refers his addressee. It makes person deixis become the most dominant deixis found in this research.

\section{CONCLUSION AND \\ SUGGESTION Conclusion}

From the data analysis, it is concluded that this research found the five deixis proposed by Levinson, they are person deixis, time deixis, place deixis, discourse deixis and social deixis. Beside that, the references found in this research were in person deixis were I, Me, We, Us, My as first person deixis; You, Your as second person deixis; He, She, It, They, Them, Him, Her as third person deixis which belong to person deixis; time deixis found were Now, Today, On a Tuesday, Three days, Two days, Then; place deixis found were Here, There, In; discourse deixis found were This, That, Those, These; and the last, social deixis found were $\mathrm{Mr}$. 


\section{Suggestion}

After conducting this research, the researcher would like to give some suggestions likely:

A. For English department students, especially who love watching the movie, it is suggested that they must understand and learn the importance of deixis, since it can help to keep away from the misinterpretation of the speaker and the addressee. Thus, it can help them to comprehend the content of the movie script more easily.

B. The researcher also whishes that there will be mentors or tutors for other researchers in deixis aspect. The researcher also hopes that the lecturers may give more explanation about deixis and its function in the utterance of spoken language. This study may give the lecturers or the teachers an inspiration to design creative strategy in teaching deixis. It will be the guidance for the teachers to make a media for teaching English especially about deixis so that the students will not bored when they learn deixis.

C. The researcher also hopes that the further researcher can conduct the research related to deixis. Thus, this study can be enlarged and developed by the researchers who are interested in analyzing the use of deixis and its meaning. Hopefully the further researcher can improve their ideas to find better research findings in English language teaching and learning process.

\section{REFERENCES}

Arikunto, Suharsimi. (2002). Prosedur Penelitian Suatu Pendekatan Praktik.Jakarta: Rineka Cipta.

Levinson, Stephen C. (1983). Pragmatics. New York. Cambridge University

Press.

Mukhtar. (2013). Metode Praktis Penelitian Deskriptif Kualitatif.

Yule, George. (1996). Pragmatics. Oxford: Oxford University Press.

\section{Online Resources}

http://www.springfieldspringfield.co.uk/ movie_script.php?movie=thousan dworda. Accessed on Thursday, 20/10/2016 